\title{
A Comparative Study of Three Plant Oils against Sitophilus oryzae (L.) and Tribolium castaneum (Herbst): Toxic and Antifeedant Effects Awadalla, S. S. ${ }^{1}$; G. M. Zayed ${ }^{2}$ and A. S. Hashem ${ }^{2}$ \\ ${ }^{1}$ Economic Entomology Department, Faculty of Agriculture, Mansoura University, Egypt. \\ ${ }^{2}$ Plant Protection Research Institute, Sakha, Kafr El-Sheikh, Egypt
}

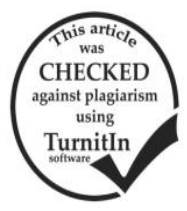

\section{ABSTRACT}

The aim of this study was to evaluate the effects of three essential oils extracted from Matricaria chamomilla flowers, Pimpinella anisum seeds and Cuminum cyminum seeds as biopesticide against Sitophilus oryzae (L.) and Tribolium castaneum (Herbst). Wherefore, the tested oils were obtained by steam distillation and evaporation of the selected plant parts and then treated at concentrations of 25000 and $50000 \mathrm{ppm}$. The weights of grains and insects were estimated before experiments taken place. After application, the mortality rates of insects, weight of grains and weight of a live insects were determined after four days. Concerning; toxic effects assay, $\mathrm{LC}_{50}$ of the oil of P. anisum $\left(\mathrm{LC}_{50}=21534.82 \mathrm{ppm}\right)$ was the most potent toxicant, followed by C. cyminum $\left(\mathrm{LC}_{50}=108310.64 \mathrm{ppm}\right)$, and $\mathrm{M}$.chamomilla $\left(\mathrm{LC}_{50}=148175.77 \mathrm{ppm}\right)$ in case of $S$. oryzae. Also, in case of $T$. castaneum, the oil of $P$. anisum $\left(\mathrm{LC}_{50}=24079.99 \mathrm{ppm}\right)$ was the most potent toxicant, followed by C. cyminum $\left(\mathrm{LC}_{50}=29980.19\right.$ $\mathrm{ppm})$, and $M$.chamomilla $\left(\mathrm{LC}_{50}=55621.91 \mathrm{ppm}\right)$.In nutritional indices assay, all the tested oils had negative effects on feeding activity of S.oryzae and $T$. castaneum, particularly with the highest concentration (50000 ppm) of all tested oils. Ultimately, the three tested oils showed effects (toxic and antifeedant) against both insect species. This study may suggest using of such essential oils as potential biopesticides to protect stored grains from infestation by the examined insects.

Keywords: Biopesticides, Essential Oils, Toxicity, Stored Grains, Nutritional Indices.

\section{INTRODUCTION}

Plant oils and their constituents are known to potentially effect on insect pests, including stored product insects (Negahban and Moharramipour 2007; Bedini et al. 2015; Park et al. 2016). Plant oils are mixtures of unstable auxiliary metabolites acquired from plants by steam distillation. The term "essential" gets from "essence," which implies smell or taste, and identifies with the property of these substances of giving particular flavors and scents to many plants. (Enan 2001; Isman 2006). Much exertion has, accordingly, been focused on plant determined materials for conceivably valuable products as commercial insect control agents (Rajendran and Sriranjini 2008).

Sitophilus oryzae L. (Coleoptera: Curculionidae) is the serious primary insects of economically important crop products such as wheat, maize, rice, grain oats and other products (Bougherra et al. 2014). The larvae must complete development inside the grain and feed on the endosperm then emerged when emptying the grain of its starchy content. While, Tribolium castaneum (Herbst) (Coleoptera: Tenebrionidae) is one of the most widespread destructive insects associated with food products and stored grain (Rees 1995), which consequently leads to damage of its food products. This insect has shown resistance to enormous range of chemical pesticides: making its control difficult to achieve. Both insect pests can cause multiple damages, either directly by feeding on the grain materials causing loss of quantity, low germination rate and/or indirectly by raising the moisture content of the grain that provides environment suitable for microbial growth and proliferation: all lead to a reduction in quantity and quality of grains (Boxall et al. 2002; Da Silva et al. 2012).

The propose of this study is to assess the potential of some oil extracts, as antifeedents, on $S$. oryzae and $T$. castaneum for the detection of nutritional indices activity and toxic effects.

\section{MATERIALS AND METHODS}

Plant oils

The dry flowers of Matricaria chamomilla and seeds of Pimpinella anisum and Cuminum cyminum were collected from different areas of Egypt. Direct steam distillation technique described by Hashem Brothers Company for Essential Oils and Aromatic Products (KafrElsohby, Kalyoubeya, Egypt) was used for obtaining crude essential oils. In which, the targeted plant parts were placed in a container equipped with condenser at which steam was passed through it carrying essential oils which condensed the vapor. Then, condensed vapor was received in a receptor separation of oil from water. Extraction time and background information about the plant species are summarized in Table 1. The excess water was removed out by adding anhydrous sodium sulphate. The obtained oil was filtered twice and stored in dark glass bottles in a refrigerator at $4{ }^{\circ} \mathrm{C}$ till their application for bioassays.

The yield of crude essential oils was estimated according to the following equation.

Dry weight of steam distillation / Dry weight of test plant Culture of insects

Adults of $S$. oryzae and T. castaneum were used in the laboratory experiments. T. castaneum was reared on broken wheat grains mixed with $5 \%$ dried yeast and $S$. oryzae on whole wheat grains in incubator at $25 \pm 1$ ${ }^{\circ} \mathrm{C}$ and $60 \pm 3$ r.h. \%, and a $10 \mathrm{~L}: 14 \mathrm{D}$ photoperiod. Adults, not separated sexually, were used in the experiments were 714 days old.

Toxic effects assay

Three replicates were prepared for each treatment and control. Mortality was recorded after 4 days from treatments and corrected according to Abbott's formula (Abbott. 1925). The 50\% lethal concentration $\left(\mathrm{LC}_{50}\right)$ and its confidential limits were determined by Probit analysis (Finney 1971).

Nutritional indices assay.

Determination of antifeedant activity of the tested oils against $S$. oryzae and $T$. castaneum was performed following the method given by Shukla et al. (2011), with slight modifications. For each type of oil, one milliliter 
(prepared in acetone) was mixed with $20 \pm 0.0001 \mathrm{~g}$ of (whole or broken) grains in glass jars thoroughly rotary shaker for $15 \mathrm{~min}$ to give the concentrations of 25000 and 50000 , then left at room temperature for $15 \mathrm{~min}$ to allow the solvent to evaporate. A control treatment (acetone only) was applied. Twenty adults of each insect previously weighed were placed into each jar (the insects used were starved for $24 \mathrm{~h}$ before beginning the experiments to standardize their levels of hunger). Three replicates were applied. The weights of grains, the weight of insects alive and mortality were determined after four days. The nutritional indices were calculated by the formulae of Farrar et al. (1989) as follows:

The relative growth rate $(\mathrm{RGR}): \mathrm{RGR}=(\mathrm{A}-\mathrm{B}) / \mathrm{B} \times$ day. The relative consumption rate (RCR): $R C R=D / B x$ day.
The efficiency of conversion of ingested food (ECI \%): ECI \% $=($ RGR $/$ RCR $) \times 100$.

A feeding deterrence index (FDI \%): FDI \% $=(C-T) / C \times 100$.

Where, $A$ is the weight of live insects, $B$ is the original weight of the insects, $\mathrm{D}$ is the ingested biomass ( $\mathrm{mg}$ ), $\mathrm{C}$ is the consumption of checked diets, and $T$ is the consumption of treated diets.

Statistical analysis

The data of mortality, loss grain weight, and antifeedant were analyzed by one-way analysis of variance (ANOVA) using SigmaPlot 12.0 software. In case of significant means separated using Fisher LSD test at 0.05 probability level. The $\mathrm{LC}_{50}$ was separated based on their 95\% CI and deemed significantly different if CIs did not overlap (e.g., Mahdian et al. 2007).

Table 1. Plant species used.

\begin{tabular}{lcccc}
\hline Plant species & Family & Common Name & Tissue collected & Extraction time \\
\hline Matricaria chamomilla & Chompositae & German chamomile & Dry flowers & Direct steam for 12 hours \\
Pimpinella anisum & Umbelliferae & Anise & Seeds & Direct steam for 8 hours \\
Cuminum cyminum & Apiaceae & Cumin & Seeds & Direct steam for 12 hours \\
\hline
\end{tabular}

\section{RESULTS}

Extraction yields and physical properties of tested oils extracts

Percentages of yield oils were $0.4,1.5$ and $5 \%$, from $M$. chamomilla, $P$. anisum and $C$ cyminum, respectively (Table 2). While, the appearance was dark blue in M. chamomilla, yellow in P. anisum and Bright yellow in $C$ cyminum. With regard to Specific Gravity (Density) at $20^{\circ} \mathrm{C}$; registered that, $(0.96,0.98$ and 0.93$)$ of M. chamomilla, P. anisum and C cyminum, respectively.

Table 2. Yield and Physical Properties of tested oils

\begin{tabular}{|c|c|c|c|}
\hline Tested oils & $\begin{array}{c}\text { Yield (\%) } \\
(w / w)\end{array}$ & Appearance & Density \\
\hline $\begin{array}{l}\text { Matricaria } \\
\text { chamomilla }\end{array}$ & 0.4 & Dark blue & 0.96 \\
\hline $\begin{array}{l}\text { Pimpinella } \\
\text { anisum }\end{array}$ & 1.5 & Yellow & 0.98 \\
\hline $\begin{array}{l}\text { Cuminum } \\
\text { cyminum }\end{array}$ & 5 & Bright yellow & 0.93 \\
\hline
\end{tabular}

${ }^{a}$ Yield of crude essential oils $=$ [Dry weight of steam distillation / Dry weight of test plant] $x 100$

\section{Antifeedant assay}

It is known that essential oils can modify nutritional indices and provoke feeding deterrence in stored insect pest. The antifeedant activity of essential oils increased with the increasing concentration (Table 3 and 4). All the essential oils had negative effects on nutritional indices of S.oryzae and $T$. castaneum. Statistical analysis showed that the most active was $M$. chamomilla oil that inhibited RGR (-0.19976713) and ECI (-85.214578), reduce significantly $(\mathrm{p}<0.05)$ the RCR at $50000 \mathrm{ppm}$ and caused a high antifeedant effect $(98.61 \%)$ on S.oryzae (Table 3). On the other hand, the most active was C.cyminum oil that inhibited RGR (0.115446515) and ECI (15.30572809), reduce significantly $(\mathrm{p}<0.05)$ the RCR at $50000 \mathrm{ppm}$ and caused a high antifeedant effect $(84.57 \%)$ on $T$. castaneum (Table 4).

Based on $95 \%$ CIs, the analysis revealed that the $\mathrm{LC}_{50}$ was significantly differed among the three essential oils on both insect examined (Table 5). The oil extracted from $M$. chamomilla recorded the highest $\mathrm{LC}_{50}$, wheres that of $P$. anisum recorded the lowest ones.

The $\mathrm{LC}_{50}$ values decreased with increasing concentration of essential oils. Based on $\mathrm{LC}_{50}$ significant differences were observed between S.oryzae and $T$. castaneum. In case of $S$. oryzae, the oil of P. anisum $\left(\mathrm{LC}_{50}\right.$ $=21534.82 \mathrm{ppm}$ ) was the most potent toxicant, followed by C. cyminum $\left(\mathrm{LC}_{50}=108310.64 \mathrm{ppm}\right)$, and $M$. chamomilla $\left(\mathrm{LC}_{50}=148175.77 \mathrm{ppm}\right)$.Also, in case of $T$. castaneum, the oil of $P$. anisum $\left(\mathrm{LC}_{50}=24079.99 \mathrm{ppm}\right)$ was the most potent toxicant, followed by C. cyminum $\left(\mathrm{LC}_{50}=29980.19\right.$ $\mathrm{ppm})$, and $M$.chamomilla $\left(\mathrm{LC}_{50}=55621.91 \mathrm{ppm}\right)$.

Table 3. Variation of nutritional indices of Sitophilus oryzae treated during 4 days with the tested oils at different concentrations

\begin{tabular}{lccccc}
\hline Source of oil & Con $\mathbf{( p p m )}$ & RGR & RCR & ECI \% & FDI\% \\
\hline P. anisum & 25000 & $-0.062 \mathrm{~b}$ & $0.344 \mathrm{a}$ & $-19.840 \mathrm{a}$ & $73.895 \mathrm{a}$ \\
Control & 50000 & $-0.186 \mathrm{~b}$ & $0.184 \mathrm{~b}$ & $-78.889 \mathrm{a}$ & $93.800 \mathrm{a}$ \\
\hline M.chamomilla & & $0.180 \mathrm{a}$ & $0.419 \mathrm{a}$ & $42.602 \mathrm{a}$ & $0.00 \mathrm{~b}$ \\
Control & 25000 & $-0.132 \mathrm{~b}$ & $0.123 \mathrm{~b}$ & $-80.134 \mathrm{~b}$ & $91.545 \mathrm{a}$ \\
C. cyminum & 50000 & $-0.199 \mathrm{~b}$ & $0.037 \mathrm{~b}$ & $-85.214 \mathrm{~b}$ & $98.611 \mathrm{a}$ \\
Control & & $0.180 \mathrm{a}$ & $0.419 \mathrm{a}$ & $42.602 \mathrm{a}$ & $0.00 \mathrm{~b}$ \\
\hline Dif & 25000 & $-0.084 \mathrm{~b}$ & $0.305 \mathrm{~b}$ & $-27.859 \mathrm{c}$ & $92.208 \mathrm{~b}$ \\
& 50000 & $-0.038 \mathrm{~b}$ & $0.074 \mathrm{c}$ & $-58.333 \mathrm{~b}$ & $94.444 \mathrm{a}$ \\
\end{tabular}

Different letters in the same column (for each oil) indicate significant differences at the 0.05 levels ( Fisher LSD)

RGR relative growth rate, RCR relative consumption rate, ECI efficiency of conversion of ingested food, FDI feeding deterrence index 
Table 4. Variation of nutritional indices of Tribolium castaneum treated during 4 days with the tested oils at different concentrations

\begin{tabular}{lccccc}
\hline Source of oil & $\begin{array}{c}\text { Con } \\
(\mathbf{p p m})\end{array}$ & RGR & RCR & ECI \% & FDI\% \\
\hline P. anisum & 25000 & $-0.133 \mathrm{~b}$ & $0.664 \mathrm{~b}$ & $-20.583 \mathrm{~b}$ & $60.489 \mathrm{~b}$ \\
Control & 50000 & $-0.589 \mathrm{c}$ & $0.022 \mathrm{c}$ & $-86.212 \mathrm{c}$ & $95.238 \mathrm{a}$ \\
& & $0.149 \mathrm{a}$ & $0.984 \mathrm{a}$ & $36.873 \mathrm{a}$ & $00.00 \mathrm{c}$ \\
M.chamomilla & 25000 & $-0.165 \mathrm{~b}$ & $0.526 \mathrm{~b}$ & $-28.782 \mathrm{~b}$ & $56.518 \mathrm{~b}$ \\
Control & 50000 & $-0.236 \mathrm{~b}$ & $0.323 \mathrm{~b}$ & $-84.183 \mathrm{c}$ & $78.564 \mathrm{a}$ \\
C.cyminum & & $0.149 \mathrm{a}$ & $0.984 \mathrm{a}$ & $36.873 \mathrm{a}$ & $00.00 \mathrm{c}$ \\
Control & 25000 & $0.087 \mathrm{a}$ & $0.881 \mathrm{~b}$ & $10.109 \mathrm{c}$ & $48.402 \mathrm{~b}$ \\
Differ & 50000 & $0.115 \mathrm{a}$ & $0.269 \mathrm{a}$ & $15.305 \mathrm{~b}$ & $84.579 \mathrm{a}$ \\
\end{tabular}

Different letters in the same column (for each oil) indicate significant differences at the 0.05 levels ( Fisher LSD)

RGR relative growth rate, RCR relative consumption rate, ECI efficiency of conversion of ingested food, FDI feeding deterrence index

Thus, $P$. anisum $\mathrm{NE}$ had the lowest $\mathrm{LC}_{50}$ value and the highest toxicity ratio for this concentration and both insects. The linear regression model was the best fit to the results of the number of adult emergence, indicating that they were inversely proportional to increasing concentrations of nanoemulsions. The $p$ value or probability value is the probability for a given statistical model that, when the invalid hypothesis is valid. The hypothesis is appropriate when $\mathrm{p}>.05$ (Nuzzo 2014); this is agreement with the all results obtained.

Table 5. $\mathrm{LC}_{50}$ values of the tested oils against Sitophilus oryzae and Tribolium castaneum

\begin{tabular}{lcccc}
\hline \multirow{2}{*}{ Insect } & Source of oil & \multirow{2}{*}{$\mathbf{C C}_{\mathbf{5 0}}{ }^{\mathbf{a}} \mathbf{( \mathbf { p p m } )}$} & \multicolumn{2}{c}{$\mathbf{9 5} \mathbf{\%}$ confidence limits (ppm) } \\
\cline { 4 - 5 } Sitophilus oryzae & P. anisum & $21534.82 \mathrm{~b}$ & 16991.13 & Upper \\
& M.chamomilla & $148175.77 \mathrm{a}$ & 118540.62 & 185219.71 \\
& C. cyminum & $108310.64 \mathrm{~b}$ & 86648.51 & 135388.31 \\
Tribolium castaneum & P. anisum & $24079.99 \mathrm{~b}$ & 20686.54 & 26935.72 \\
& M. chamomilla & $55621.91 \mathrm{a}$ & 51358.38 & 59985.01 \\
& C. cyminum & $29980.19 \mathrm{~b}$ & 19915.69 & 37728.01 \\
\hline
\end{tabular}

${ }^{a}$ LC50 values are after $96 \mathrm{~h}$, The same letters in a coulumn are not significantly differed among LC50 based on $95 \%$ CIs.

\section{DISCUSSION}

The oil yield is an important element to express some of its advantages and characteristics such as the quantity extracted from the quantity of a specific crop and its economic feasibility and commercial production (Vitti and Brito 1999). In the present investigation, the yield of $P$. anisum seeds was in the range of $1.5-3.5 \%$ similar to those previously reported (Olle and Bender. 2010; Habib Ullah et al. 2014). While, the yield of $M$. chamomilla dry flowers was in the range of $0.3-0.9 \%$ (Guzelmeric et al. 2017; Kawthar et al. 2017) and that of C. cyminum seeds was in the range of $3.5-5.5 \%$ (Hajlaoui et al. 2010; Khan et al. 2017). However, the yield concentrations for the tested oils were fluctuating and different, both increasing and decreasing. These differences might arise from oil extraction technique, the initial plant mass, and the used plant part (AttiSantos et al. 2005).Besides, high polarity solvent (ethanol, methanol and aqueous acetone) always gives the highest yield of crude extract (Poonsri et al. 2015), in addition to, an environmental condition, processing technology and genetic constituents influences the yield of essential oil (Saxena et al. 2015).

Jilani et al. (1988) announced that turmeric oil high as a repellent to different grain insects. While, plant oils of clove was toxic to Rhyzopertha dominica (F.) and S. oryzae (L.) (Sighamony et al. 1986). In the same context, the essential oil of anise (P. anisum.) and peppermint (Mentha piperita L.) have been found to have toxicity through fumigant to stored grain against four main stored product pests $T$. castaneum, $S$. oryzae Orzyaephilus surinamensis and $R$. dominica, (Shaaya et al. 1991). Huang et al. 1997, proved that, the essential oils of nutmeg seeds (Myristica fragrans Houtt) and cinnamon bark (Cinnamomum aromaticum Nees) were toxic and antifeedant of $T$. castaneum and $S$. zeamais. These previous studies are consistent with this results obtained.

\section{REFERENCES}

Abbott W.S. 1925. A method of computing the effectiveness of an insecticide. J. Econ. Entomol., 18(2), 265-267.

Atti-Santos A.C., Rossato M., Pauletti G.F., Rota L.D., Rech J.C., Pansera M.R., and Moyna P. 2005. Physico-chemical evaluation of Rosmarinus officinalis L. essential oils. Braz. Arch. Biol. Technol., 48(6), 1035-1039.

Bedini S., Flamini G., Girardi J., Cosci F., and Conti B. 2015. Not just for beer: evaluation of spent hops (Humulus lupulus L.) as a source of eco-friendly repellents for insect pests of stored foods. J. Pest. Sci., 88:583-592.

Bougherra H. H., Bedini S., Flamini G., Cosci F., Belhamel K., and Conti B. 2015. Pistacia lentiscus essential oil has repellent effect against three major insect pests of pasta. Ind. Crops Prod., 63, 249-255. 
Boxall R. A., Brice J. R., Taylor S. J., and Bancroft R. D. 2002. Technology and management of storage. In P. Golob, G. Farrell, \& J. E. Orchard (Eds.), Crop postharvest: Science and technology, principles and practice (pp. 141232). Natural Resource Institute, University of Greenwich, 1.

Da Silva P., Eyraud V., Carre-Pierrat M., Sivignon C., Rahioui I., and Royer C., 2012. High toxicity and specificity of the saponin 3-GlcA- 28 AraRhaxylmedicagenate, from Medicago truncatula seeds, for Sitophilus oryzae. BMC Chemical Biology, 12, 3.

Enan E.E. 2001. Insecticidal activity of essential oils: octopaminergic sites of action. Comp. Biochem. Physiol. 130:325-327.

Farrar R.R., Barbour J.D., and Kennedy G.G., 1989. Quantifying food consumption and growth in insects. Ann. Entomol. Soc. Am., 82(5), 593598.

Finney D.J. 1971. Probit Analysis: 3d Ed. Cambridge University Press.

Guzelmeric E., Ristivojević P., Vovk I., MilojkovićOpsenica D., and Yesilada E., 2017. Quality assessment of marketed chamomile tea products by a validated HPTLC method combined with multivariate analysis. J. Pharm. Biomed. Anal., 132, 35-45.

Habib Ullah Mahmood A., and Honermeier B., 2014. Essential oil and composition of anise (Pimpinella anisum L.) with varying seed rates and row spacing. Pak. J. Botany, 46, 1859-1864.

Hajlaoui H., Mighri H., Noumi E., Snoussi M., Trabelsi N., Ksouri R., and Bakhrouf A., 2010.Chemical composition and biological activities of Tunisian Cuminum cyminum L. essential oil: A high effectiveness against Vibrio spp. strains. Food Chem. Toxicol, 48(8), 2186-2192.

Huang Y., Tan J.M.W.L., Kini R.M., and Ho S.H., 1997. Toxic and antifeedant action of nutmeg oil against Tribolium castaneum (Herbst) and Sitophilus zeamais Motsch. J. Stored Prod. Res. 33, 289-298.

Isman M.B., 2006.Botanical insecticides, deterrents, and repellents in modern agriculture and an increasingly regulated world. Ann. Rev. Ent. 51:45-66.

Jilani, G., Sazena, R.C., Rueda, and B.P., 1988. Repellent and growth-inhibiting effects of turmeric oil, sweetflag oil, neem oil, and "Margosan-O" on red flour beetle (Coleoptera: Tenebrionidae). J. Econ. Entomol., 81, 12261230.

Kawthar A.E., Ashour H.M., Fatma S.I., 2017. Growth Characters and some Chemical Constituents of Matricaria chamomilla L. Plants in Relation to Green Manure and Compost Fertilizer in Sandy Soil. Middle East J, 6(1), 76-86.
Khan I.U., Mehriya M.L., Rathore B.S., Kumhar S.R., and Singh B., 2017. Evaluation of volatile phytochemical constituents in cumin (Cuminum cyminum) genotypes by gas chromatography mass spectroscopy. J. Pharmacogn. Phytochem., 6(3), 768-773.

Mahdian, K., Tirry, L., \& De Clercq, P. (2007). Functional response of Picromerus bidens: effects of host plant. J. Appl, Entomol. 131: 160 164.

Negahban M., and Moharramipour S., 2007. Fumigant toxicity of Eucalyptus intertexta, Eucalyptus sargentii and Eucalyptus camaldulensis against stored-product beetles. J. Appl. Entomol., 131:256-261.

Nuzzo, R., 2014. Scientific method: Statistical errors: P values, the 'gold standard of statistical validity, are not as reliable as many scientists assume. Nature, 506 (February), 150-152.

Olle M., Bender I., and Koppe R., 2010.The content of oils in umbelliferous crops and its formation. Agronomy Research, 8(3), 687-696.

Poonsri W., Pluempanupat W., Chitchirachan P., Bullangpoti V., and Koul O., 2015. Insecticidal alkanes from Bauhinia scandens var. horsfieldii against Plutella xylostella L.(Lepidoptera: Plutellidae). Ind. Crops Prod., 65, 170-174.

Rajendran S., and Sriranjini V., 2008.Plant products as fumigants for stored-product insect control. J. Stored Prod. Res. 44:126-135.

Rees D.P., 1995. Coleoptera. In: Subramanyam Bh, Hagstrum DW (eds) Integrated management of insects in stored products. Marcel Dekker, New York, pp 1-39.

Saxena S.N., Sharma Y.K., Rathore S.S., Singh K.K., Barnwal P., Saxena R., and Anwer M.M., 2015. Effect of cryogenic grinding on volatile oil, oleoresin content and anti-oxidant properties of coriander (Coriandrum sativum L.) genotypes. J. Food Sci. Technol., 52(1), 568-573.

Shaaya E., Ravid U., Paster N., Juven B., Zisman U., and Pissarev V., 1991. Fumigant toxicity of essential oils against four major stored-product insects. J. Chem. Ecol., 17, 499-504.

Shukla R., Singh P., Prakash B., Kumar A., Mishra P.K., Dubey N.K., 2011. Efficacy of essential oils of Lippia alba (Mill.) NE Brown and Callistemon lanceolatus (Sm.) Sweet and their major constituents on mortality, oviposition and feeding behaviour of pulse beetle, Callosobruchus chinensis L. J. Sci. Food Agric., 91(12), 2277-2283.

Sighamony S., Anees I., Chandrakala T., Osmani J., 1986. Efficacy of certain indigenous plant products as grain protectants against Sitophilus oryzae (L.) and Rhyzopertha dominica (F.). J. Stored Prod. Res. 22, 21-23.

Vitti A.M.S., and Brito J.O., 1999. Avaliaçao do rendimento e do teor de citronelal do óleo essencial de procêdencias e raças de Eucalyptus citriodora. Sci. For. 56, 145-154. 
دراسة مقارنة لثلاثة زيوت نباتية ضد حشرتى سوسة الارز Sitophilus oryzae (L.) وخنفساء الدقيق الصدئية : Tribolium castaneum (Herbst)

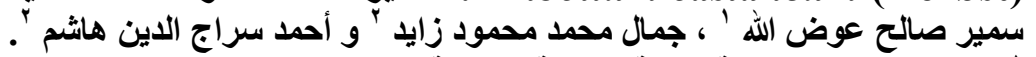

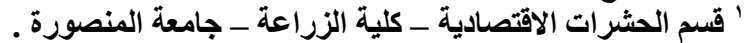

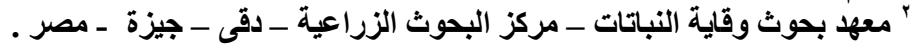

تهدف هذه الدراسة الى تقييم تاثير الزيوت الاساسية المستخلصة من البابونج الالمانى ( زهور ) ونبات اليانسون (بذور ) ونبات الكمون (بذور)

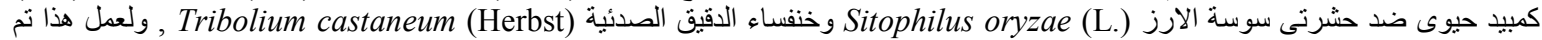

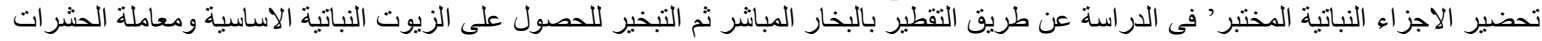

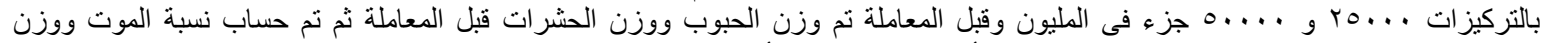

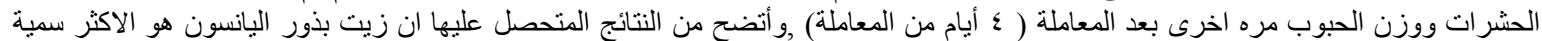

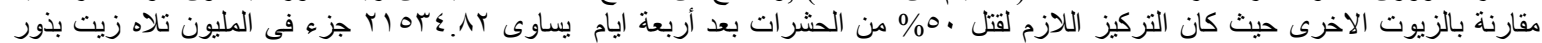

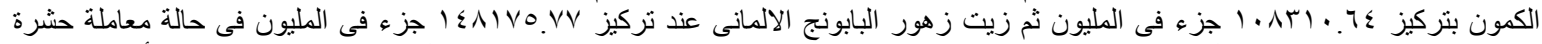

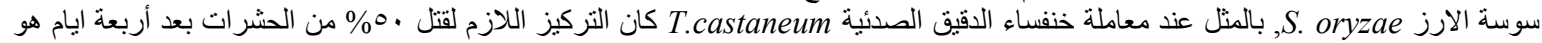

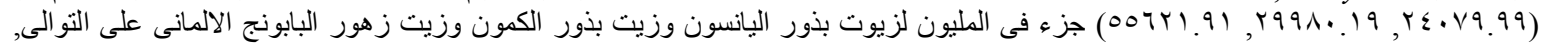

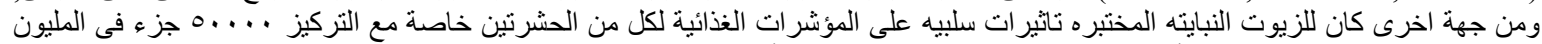

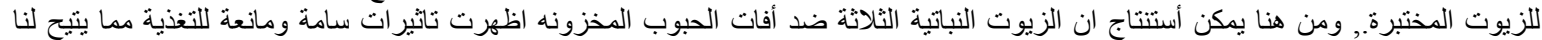
استخدامها كاستير اتيجيات جديدة في وقاية الحبوب المناج ان المخزونة. 